\title{
Unemployment Insurance Reform - 199I-2006: A New Balance between Rights and Obligations in France, Germany, Portugal and Spain
}

\section{Manuela Arcanjo}

\begin{abstract}
The purpose of this article is twofold. First, focusing on unemployment insurance schemes, the article seeks to identify the development of social rights and obligations in four countries (France, Germany, Portugal and Spain), representative of the conservative regime, over the period I99I2006. Second, the article aims to verify whether or not there was a common reform trajectory in time as well as in space, given the already known divergence over the appropriateness of classifying Mediterranean countries within the framework of a specific regime.

Based on analysis of 25 legislative changes concerning entitlement and eligibility criteria, the study presents three major findings. First, the four insurance schemes reveal a new balance between (weaker) social rights and (stronger) obligations, which may indicate a trend toward a re-commodification of work. Second, Portugal adopted a specific trajectory while the Spanish reform process more closely resembled that carried out by France and Germany. Finally, two waves of reform may be identified: first, between I99I and 1997 and justified by cost-containment concerns and, subsequently, from $200 \mathrm{I}$ onwards, associated with a stronger recalibration of benefit rights.
\end{abstract}

\section{Keywords}

Welfare state reform; Conservative regime; Unemployment insurance schemes; Social rights and obligations

\section{Introduction}

Since the mid-I9gos, a large body of literature has been devoted to analysis of welfare state reform, particularly in Western Europe, by virtue of the important challenges shared to a greater or lesser extent by all countries. External pressures (globalization) and/or internal pressures (especially ageing populations, slower economic growth, high and persistent unemployment and

Address for correspondence: Manuela Arcanjo, ISEG/UTL - School of Economics and Management, Technical University of Lisboa, Rua Miguel Lupi, 20, Room 218, I249-o78 Lisbon, Portugal. Email: marcanjo@iseg.utl.pt 
European monetary-related constraints on public spending) have been identified as the major drivers of social change (e.g. Ferrera and Rhodes 2000; Kuhnle 2000; Huber and Stephens 200i; Pierson 200ia; Powell and Hewitt 2002; Castles 2004; Kittel and Winner 2005).

For more than a decade, the interest of many researchers has been focused on the nature and degree of welfare change, particularly old-age pensions and health care as the two major programmes in terms of coverage and expenditure. In addition, some researchers have also attempted to identify differences in the dynamics of reforms enacted in different welfare regimes.

Despite the reforms undertaken in all EU countries since the Ig8os, unemployment protection has attracted the attention of few researchers (e.g. Clasen et al. 200r; Clasen and Clegg 2006; Clegg 2007). Not only is this the third largest social programme in many European welfare states, especially during periods of high and persistent unemployment, but such state expenditure has also commonly been subject to several criticisms. Beyond the twofold negative effect on public expenditure and revenue, many critics of this social programme point to potential work disincentives: the easier to access and the more generous the benefits, the greater its effect on the length of time spent unemployed and, therefore, the greater the level of state dependency.

In itself, this kind of criticism cannot explain the lower popularity of this social programme but such a prevailing opinion may have had some influence over the nature of reforms implemented in the last decade (Kvist I998, 2000; OECD 2000; Zimmermann 2006). More specifically, if we assume a reduction in the depth and breadth of such polices was a priority in restructuring unemployment protection, then policy measures may be expected to reflect this option. Thus, it is expected that governments chose to make access stricter and/or reinforce claimant obligations rather than reduce levels of benefit payments - by changes in earnings references, replacement rates and the incidence of taxation. Where the former represent the options taken, then we might accept that unemployment protection reform resulted in a new balance between (weaker) rights and (stronger) obligations.

In order to verify the validity of this hypothesis, the present article analyses the reform of unemployment insurance schemes in Germany, France, Portugal and Spain, as representative of the conservative regime, for the period I99I-2006. We analyze 25 legislative changes concerning eligibility and entitlement criteria as stipulated in legislation in the four countries. Given the well-known divergence over the classification of Mediterranean countries, the selection of Portugal and Spain - two less frequently studied countries enables us to verify whether or not the reform process followed a specific and shared trajectory. Furthermore, our objectives also include verifying whether there was a common reform trajectory in time or, on the contrary, the process of reform confirms the two main waves identified by some authors (e.g. Palier 2007; Palier and Martin 2007).

The structure of the article is as follows. In the next section, we briefly discuss three topics: the reasons for unemployment protection reform, the instruments and trajectory over time; the classification of the four countries in accordance with their respective welfare regime and, finally, the selection of the most appropriate indicators. The second section identifies the legislative 
changes between I99I and 2006 according to each rule on eligibility and entitlement and by country. The third section provides a brief analysis of the direction of all changes in the four countries before the fourth section discusses our conclusions.

\section{Analysis of Unemployment Protection Reform}

\section{Reasons for reform and the trajectory in time}

For a long time, empirical research across European countries focused mainly on retirement pensions as the major social programme in both financial terms and beneficiary numbers (e.g. Myles and Quadagno I997; Taylor-Gooby I999; Bonoli 2003; Schludi 2005; Bonoli and Palier 2007; Jochem 2007). More recently, unemployment protection reform across a group of European countries has also become the analytical focus of some empirical studies (e.g. Clasen et al. 200i; Clasen and Clegg 2006; Clegg 2007).

Despite being a social programme with more restricted coverage, and therefore much less expensive when compared with old-age pensions, unemployment protection has also been the subject of substantial legislative changes in all western European countries over the last two decades.

Three motives serve to explain the political option of reforming unemployment protection. First, there is an important economic argument insofar as persistently high unemployment has a twofold negative effect on public budgets by increasing social expenditure and lowering tax and/or social contribution revenues (Clasen 2000). A second motive takes into account the social limits of traditional unemployment insurance schemes within the context of new labour market conditions, namely, atypical forms of working and long-term unemployment (Clasen and Clegg 2006). Although these two reasons may be sufficient to explain changes in eligibility and entitlement rules, we believe that the neo-liberal thesis concerning beneficiary behaviour may have been decisive. As several authors point out (Kvist I998; OECD 2000; Scruggs 2006), this social programme is usually criticized for its potential work disincentives: the easier it is to access and the more generous the benefits, the greater its potential effect on the length of time spent unemployed and, therefore, the greater the dependency on the state.

This kind of criticism helps in explaining the lower popularity of this social programme. According to Taylor-Gooby (200г: I39), a selective programme such as unemployment protection has, in contrast with those providing comprehensive coverage (such as old-age pension schemes), less public support which can be explained by the perception that such benefits 'are less legitimate, or because they command a weaker constituency of self-interest'. ${ }^{1}$ Thus, instead of a blame-avoidance strategy designed to minimize the impact on public opinion (Pierson 200Ib), unemployment protection reform may be seen as a way for governments to obtain credit-claiming (Clasen 2000: I08). Thus, any reform that focuses on integrating unemployed persons into the labour market might be expected to gain the public support of tax-payers.

These three reasons, taken together, may justify the two dimensions of the reform agenda in the European countries identified by Clegg (2006: 7-6): 
cost-containment (realized through cuts in levels and/or duration of benefits, and/or stricter eligibility criteria) and the recalibration of benefit rights (realized through measures such as safeguarding protection for those with atypical work histories, reducing protection even for those with long working histories and more contribution-based benefit entitlements). However, the 'precise mix of the different measures of course varies in space and time' (Clegg 2006: 7).

Regarding the process of reform over time, more precisely since I990, several authors (e.g. Palier 2007; Palier and Martin 2007; Hemerijck and Eichhorst 2009) identified two main stages to welfare state reform: a first wave of retrenchment in the early I99os and a second wave of more path-breaking changes in the 2000 .

The first is associated both with the economic downturn in the I99 ${ }^{-}-93$ period and with the adoption of the Maastricht criteria in I993. This economic and political context would justify several measures aimed at controlling social expenditure in the fields of pensions, health care and unemployment. The second wave of reforms targeted not only containing social benefits but also implementing more structural changes, such as the introduction of funded pension schemes, the privatization of health-care systems and the activation of the unemployed persons (Palier and Martin 2007: 543).

Taking these arguments into account, we intend verify whether these two waves have been observable in the trajectories of unemployment reform undertaken in our four selected countries.

\section{The continental and Mediterranean countries: one or two welfare regimes?}

Following the line of research adopted by several authors in recent years, our four-country (France, Germany, Portugal and Spain) comparative analysis takes the welfare regime approach as its theoretical background.

One obvious question concerns the classification of these countries, given the intense academic debate launched by the publication of The Three Worlds of Welfare Capitalism by Esping-Andersen (I990), which remains a point of reference work despite the diverse subsequent critiques (see Powell and Barrientos 20II).

There is a consensus on classifying France and Germany within the same welfare regime, despite the different names attributed: conservative (EspingAndersen I990), Bismarckian (Ferrera I996), or continental (Bonoli I997). This does not hold for the classification of Portugal and Spain, as well as for the other two Mediterranean countries.

Indeed, one field of criticism of the 'three worlds' deals with the incorrect classification of certain countries, particularly, Italy. The proposal of a fourth regime to encompass the four Mediterranean countries resulted in the presentation of new typologies (e.g. Leibfried I992; Ferrera I996; Bonoli I997). This specific regime was justified by two main reasons:

I. the role of the family as the major social protection provider; and

2. substantial variations in the quality of social protection arrangements across fields of social policy. 
In Social Foundations of Post-Industrial Economies, Esping-Andersen (I999) acknowledged how Mediterranean countries presented characteristics not entirely compatible with his 'three worlds' and argued that establishing a specific regime would depend principally on the role of the family in the welfare mix. To this end, Esping-Andersen identifies and assesses two dimensions to familialism (public policies aimed at families and the welfare burden assumed by the latter), arguing that Spain, Portugal and Italy (Greece was excluded) do not justify classification under a specific regime, given these countries display no significant differences when compared with other continental European countries, namely, France and Germany (Esping-Andersen I999: 93).

Relating the aforementioned polarization of their material coverage, including serious gaps in protection, we argue this can only be explained by pointing to the lower level of welfare state development (EC I993; Katrougalos I996; Vogel 2003; Arcanjo 2006). Moreover, developments observed in Greece, Portugal and Spain in recent decades 'indicate remarkable progress from rudimentary to some of fully fletched welfare states' (Palme et al. 2009: 24).

However, this question remains unresolved by empirical studies: some backing the existence of a specific regime (e.g. Kautto 2002; Saint Arnaud and Bernard 2003; Soede et al. 2004), while others classify such countries in different clusters (e.g. Gough 200I; MacMenamim 2003; Powell and Barrientos 2004).

Specifically regarding unemployment protection, the existence of a specific model for Mediterranean countries was set out by Gallie and Paugam (2000). Based on three indicators (coverage, average assistance and insurance benefit expenditure per unemployed person as a percentage of GDP, and expenditure on active employment policies as a percentage of GDP), and using data from the early I9gos, the authors identified four 'unemployment welfare regimes' (Gallie and Paugam 2000: 5). Our four countries are clustered into two different models: France and Germany in the employment-centred model (generous benefits, unequal levels of coverage and extensive active employment policies) with Spain and Portugal in the sub-protective model (low benefits, very incomplete coverage and quasi non-existent active employment policies). Despite this differentiation, the authors stated that "while the most notable feature of [this model] is the gaps in their provision, it is possible none the less to detect a Bismarckian influence' (Gallie and Paugam 2000: 9).

Indeed, we argue that the very incomplete coverage of the Mediterranean countries as well as low benefit amounts may have two reasons: the aforementioned under-development of their welfare states and, particularly, their respective labour market characteristics: high rates of temporary employment and lower salaries in comparison with France and Germany. As we find later, the four countries share important institutional features. Therefore, similar to many other scholars, we propose social protection in the Mediterranean countries merely constitutes a variant on the conservative model.

The traditional institutional features of social rights in conservative unemployment insurance schemes are well identified (e.g. Kvist I998; Clasen 200i; Zimmermann 2006; Palier and Martin 2007): rights derived from employment 
and occupational status; access to benefits and the duration of payment dependent upon the length of the insurance career; earnings-related benefits and expressed by generous replacement rates with weak levels of sanctions. All such features explain the medium level of decommodification found by Esping-Andersen (1990). However, how many of these features have been changed by the reform process carried out during the last I5 years? Did the four countries present a similar reform trajectory or, on the contrary, did the two Mediterranean countries deviate from France and Germany? We proceed with answering these questions in the second section.

\section{The most appropriate indicators}

One important methodological option relates to selecting the most appropriate indicator for measuring welfare change. This debate was first set forth by Esping-Andersen (I990: I9), who rejected the conceptualization of welfare states in terms of social expenditure. Since then, expenditure indicators have come in for criticism from several authors (e.g. Pierson 1996; Korpi 2003; Green-Pedersen 2004; Allan and Scruggs 2004; Scruggs 2006; Castles 2008).

With regard to unemployment policy, social expenditure as a GDP percentage presents three major limitations: expenditure rises due to increasing levels of unemployment without any change in eligibility and entitlement rules, with differences in either national growth rates or in the taxation of benefits potentially distorting cross-national comparisons.

However, it is important to bear in mind that the share of unemployment expenditure does not always correlate with the unemployment rate as demonstrated below for the countries selected (table I).

For example, in I990, the level of unemployment expenditure showed no expressive deviation in France and Germany, despite significantly different unemployment rates. In 2006, expenditure on the Spanish scheme was double that of the Portuguese scheme while the unemployment rates stood at 8.5 per cent and 7.8 per cent respectively. In addition to the differing levels of GDP growth, these disparities reveal very different degrees of coverage and/or generosity.

Throughout this I7-year period, European countries faced two major periods of economic downturn: at the beginning of the I990s (I99I-93) and in the 2002-03 period. Rising and high unemployment rates followed in our four countries for periods varying between four and six years. It would be expected that unemployment expenditure experienced similar trends. However, some figures reveal an opposite movement. The decrease in I994, with the exception of Portugal where unemployment rates underwent a rise, is explainable by legislative changes. The upsurge in unemployment in France and Germany over the period 2002-04 did not lead to higher social expenditure which may, once again, be explained by unemployment protection scheme reforms.

From the I990-2006 figures, we may conclude that the quantitative measure is not the best indicator because it ignores cross-national variations and changes over time in both the coverage and the generosity of unemployment protection schemes. 
Table I

Standardized unemployment rates and unemployment expenditure as a percentage of GDP

\begin{tabular}{|c|c|c|c|c|c|c|c|}
\hline & I990 & I993 & I996 & I999 & $200 \mathrm{I}$ & 2004 & 2006 \\
\hline \multicolumn{8}{|l|}{ France } \\
\hline UEX/GDP & 2.3 & 2.7 & 2.3 & 2.1 & 2.0 & 2.3 & 2.0 \\
\hline$U R$ & 8.5 & II.I & II. 6 & 10.5 & 8.4 & 9.6 & 9.2 \\
\hline \multicolumn{8}{|l|}{ Germany } \\
\hline UEX/GDP & I.7 & 2.9 & 2.6 & 2.5 & 2.4 & 2.4 & I. 7 \\
\hline$U R$ & 4.8 & 7.7 & 8.6 & 7.9 & $7 \cdot 4$ & $9 \cdot 5$ & 9.8 \\
\hline \multicolumn{8}{|l|}{ Portugal } \\
\hline UEX/GDP & 0.5 & I.O & I.I & 0.7 & 0.7 & I. 3 & I. 3 \\
\hline$U R$ & 4.8 & 5.6 & $7 \cdot 3$ & 4.5 & 4.0 & 6.7 & 7.8 \\
\hline \multicolumn{8}{|l|}{ Spain } \\
\hline UEX/GDP & 3.5 & $5 \cdot \mathrm{I}$ & 3.1 & 2.4 & 2.4 & 2.5 & 2.6 \\
\hline$U R$ & I3.I & I8. 6 & 17.8 & 12.5 & 10.3 & Io. 6 & 8.5 \\
\hline
\end{tabular}

Source: Eurostat 200I, 2004, 2008a, 2008b; OECD 2005, 2006, 2008.

Notes: UEX/GDP = unemployment expenditure as \% of GDP.

$\mathrm{UR}=$ unemployment rates.

Thus, a social rights-based approach seems a preferable alternative for analyzing developments in any specific area of social policy and especially unemployment protection. However, one further question remains: Which indicator is most appropriate for measuring social rights?

First of all, there is the unemployment protection decommodification index proposed and constructed by Esping-Andersen (I990) with the assessment of some indicators - such as the contribution period, net replacement rate and take up rate - which may be 'capable of providing evidence of quite subtle changes in the quality of social provision' (Clegg and Clasen 2003:6). The limitation is that this captures all changes in eligibility and entitlement criteria, specifically all the terms and conditions of access as well as the conditions for continuing to receive unemployment benefits.

The net replacement rate as a measure of social rights was used, for example, by Korpi and Palme (2003) who analyzed unemployment insurance (1975-95) in OECD countries. Compared to expenditure data, this indicator has the advantage of not being affected by increases in the number of beneficiaries but cannot capture every change in eligibility and entitlement rules (Pallage et al. 2008: 2).

In recent years, the debate points to the main objectives of unemployment protection having changed: the so-called passive policy became secondary and a 'return to work at all costs has become the paragon of social policy' (Clasen 2000: 38). As a result, we can speak of a new nexus between social rights and obligations (Kvist 2000: 2) that can be summarized as follows: 'rights are no longer automatically guaranteed and are accompanied by a whole range of incentives and sanctions' (Zimmermann 2006: 39). There is no 
doubt that all the above mentioned indicators are proven and able to characterize all the qualitative changes relating to eligibility, entitlement and obligations, including sanctions.

Based on the typology approach and focused on unemployment protection, three interesting empirical studies (Clasen et al. 200I; Clasen and Clegg 2006; Clegg 2007) analyzed the legislative changes carried out through to 2003 in eight European countries (Denmark, Sweden, Finland, Netherlands, Belgium, the UK, France and Belgium).

In keeping with this line of research, we base our analysis on six criteria that encompass eligibility (qualifying period and main conditions of payment) and entitlement (reference earnings and rates of benefits, duration of payment and taxation), in order to characterize the direction of changes introduced over time as well as to identify differences and similarities across the four national schemes. The analysis is limited to legislative changes introduced in insurance schemes within a context of full unemployment over the period I99I-2006. This period includes 25 major reforms: France (1992, I996, 2001, 2002, 2003, 2005 and 2006); Germany (1994, I995, I997, 1998, 2002, 2003, 2004, 2005 and 2006); Portugal (I999, 2003 and 2006); and Spain (I992, I994, 200I, 2002, 2004 and 2006).

We sourced our core data from the Mutual Information System on Social Protection in the Member States of the European Union (MISSOC). The information reported annually by the European Commission makes it possible to identify the main changes that have occurred in each country. Moreover, three further complementary sources were used: the database of the International Reform Monitor (Portugal not included), NATLEX from the International Labour Office (ILO), and the Social Security Databases from the International Social Security Association. ${ }^{2}$

\section{The Institutional Ghanges between 1991 and 2006}

The literature concerned with the institutional design of unemployment compensation usually identifies three methods of protection: an insurance system (eligibility depends on the individual's contribution record and benefits are earnings-related), an assistance system (eligibility depends on means testing and benefits are flat-rate), or a combination of these two schemes into a dual system. In I99I, all the four countries analyzed operated a dual system. In all insurance schemes, membership is compulsory, following the contributory principle, which is a means of avoiding adverse selection (Kvist I998: 40). All countries restrict social protection to wage earners and pay the typical earnings-related benefits. ${ }^{3}$ Next, we proceed to analyze the changes in the four countries during the period studied in addition to the means of implementation according to the respective legal parameters and rules concerning eligibility and entitlement.

\section{Eligibility: qualifying period}

The purpose of the qualifying period is to limit benefit eligibility to claimants who fulfil certain working requirements, which may be expressed through 
Table 2

Qualifying period under the insurance scheme

\begin{tabular}{|c|c|c|c|c|c|}
\hline & I99I & I992 & $200 \mathrm{I}$ & 2002 & 2004 \\
\hline FR & $\begin{array}{l}3 \mathrm{M} \text { in last } \\
8 \mathrm{M}\end{array}$ & $\begin{array}{l}4 \mathrm{M} \text { in last } \\
8 \mathrm{M}\end{array}$ & $\begin{array}{l}4 \mathrm{M} \text { in last } \\
\mathrm{I} 8 \mathrm{M}\end{array}$ & $\begin{array}{c}6 \mathrm{M} \text { in last } \\
22 \mathrm{M}\end{array}$ & - \\
\hline $\mathrm{DE}$ & $\begin{array}{l}\text { I2 } \mathrm{M} \text { in last } \\
3 \mathrm{Y}\end{array}$ & - & - & - & $\begin{array}{l}\text { I2 } \mathrm{M} \text { in last } \\
2 \mathrm{Y}\end{array}$ \\
\hline PT & $\begin{array}{l}\text { I8 } \mathrm{M} \text { in } \\
\text { last } 2 \mathrm{Y}\end{array}$ & - & - & - & - \\
\hline SP & $\begin{array}{c}6 \mathrm{M} \text { in last } \\
6 \mathrm{Y}\end{array}$ & $\begin{array}{l}\text { I2 } \mathrm{M} \text { in last } \\
6 \mathrm{Y}\end{array}$ & - & - & - \\
\hline
\end{tabular}

Source: MISSOC (several years); ILO 2007; ISSA 2008.

three factors: a minimum work record, a relevant work period and intensity of employment (Clasen et al. 200I). In all four countries, the work requirement has been expressed by a minimum work record and a relevant period of employment (table 2).

In order to facilitate the comparative analysis, as well as that of the extent of changes, we have calculated the ratio between the first two factors mentioned above (Clasen et al. 200I).

In I99I, the countries were ranked as follows: Spain (o.o8), Germany (o.33), France (0.34) and Portugal (0.75). Throughout the period under review, the picture changed in three countries, where the work requirement showed a reverse trend:

I. in Spain (in I992) and in Germany (only in 2004), the qualifying period became more stringent (the ratio rose to 0.17 and $0.5^{\circ}$, respectively);

2. in France, the work requirement registered three changes, with increases in 1992 and 2002 (the ratio amounted 0.27 , one of the more generous) which seems to coincide with the two periods of economic crises already mentioned.

Portugal and Spain enacted no changes. ${ }^{4}$ The increase in the work-relatedness resulting from reforms in other European countries (for example, the UK, Netherlands, Belgium and Finland) is only evident in Germany and Spain.

\section{Eligibility: the main payment conditions}

In I99I, the four insurance schemes all required claimants to be involuntarily unemployed, registered at a public employment office and capable of, and available for, work. However, the conditions necessary to qualify for unemployment insurance, including conditions for continuing to receive a benefit became progressively more restrictive. 
Stricter definitions of availability for work in relation to active job-seeking and acceptance of job offers (definition of a suitable job and geographical mobility rules) were introduced into all four insurance schemes.

In the late-I99os - as was the case of Germany, in I998 - and after 200I, individual activity requirements were reinforced by re-integration contracts, including mandatory participation in labour market programmes (e.g. OECD 2000, 2005, 2007). In all countries, personalized re-integration contracts became a 'tool to enforce the eligibility criteria so that unemployment benefit conditionality has become stricter over time' (Eichhorst and Konle-Seidl 2008: Io) with unemployment compensation becoming a kind of assistance in returning to work and a reward for active job seeking. The PARE (Plan d'Aide au Retour l'Emplor), initiated in France in 200 I, represents one good example: all newly unemployed citizens were required to subscribe to the programme to qualify for benefits. However, some diversity is observed between countries (OECD 2007) and we find two distinct situations in the unemployment action plans put into practice:

I. after registration at an employment office (Germany and France);

2. three (or six) months in the case of youths or six (or I2) months in the case of adults after registration (Portugal and Spain, respectively).

In all countries, these obligations have been accompanied by a more intensive monitoring of individual jobseeker activities, particularly contacts with employment offices as well as tougher sanctions on those rejecting training courses or job offers. ${ }^{5}$ Once again, there are very sharp variations among countries. For example, the sanction for a first refusal may be the suspension of unemployment benefit as from I2 weeks (Germany) to three months (France and Portugal) or a definitive exclusion (Spain). However, it is very difficult to access how these punitive sanctions are implemented in practice (OECD 2005).

Observed together, these measures can be classified as a major change in unemployment protection. Indeed, even if almost no other legal parameters had been altered, the greater emphasis on obligations (and consequently sanctions) weakened the traditional relationship between contribution and eligibility requirements. Moreover, this new conditionality may have forced unemployed people to accept even very low paid jobs that moved them down onto a lower level of social protection.

\section{Entitlement: reference earnings and rates of benefits}

We now turn to the factors that determine the amount of unemployment insurance benefits, i.e. the (gross) rates of replacement (table 3 ) and the earnings taken as reference (table 4 ).

A system of rates is used by three countries: in Germany, the rates vary according to family status (better for claimants with children), while in France and Spain, the rate decreases according to the length of unemployment (better for short-term unemployment). We find that in I99 I the replacement rate varied between 57.4 per cent (France) and 80 per cent (Spain). Depending 
Table 3

Rates of unemployment insurance benefits

\begin{tabular}{|c|c|c|c|c|c|}
\hline & I99I & I992 & I996 & I997 & $200 \mathrm{I}$ \\
\hline FR & $\begin{array}{l}40.4 \%+\text { a flat } \\
\text { rate or } 57 \cdot 4 \% \\
\text { within a limit } \\
\text { of } 75 \%\end{array}$ & $\begin{array}{l}\text { Downward } \\
\text { sliding scale: } \\
\text { the full rate is } \\
\text { decreased } \\
\text { every } 4 \mathrm{M}\end{array}$ & $\begin{array}{l}\text { Downward } \\
\text { sliding scale: } \\
\text { the full rate is } \\
\text { decreased } \\
\text { every } 6 \mathrm{M}\end{array}$ & - & $\begin{array}{l}\text { Fixed } \\
\text { scale }\end{array}$ \\
\hline DE & $\begin{array}{l}68 \% \text { or } 63 \% \\
\text { (no children) }\end{array}$ & - & & $\begin{array}{l}67 \% \text { or } 60 \% \\
\text { (no children) }\end{array}$ & \\
\hline PT & $65 \%$ & - & - & - & - \\
\hline SP & $\begin{array}{r}80 \% \text { or } 70 \% \\
\quad(\text { after } 6 \mathrm{M})\end{array}$ & $\begin{array}{r}70 \% \text { or } 60 \% \\
(\text { after } 6 \mathrm{M})\end{array}$ & - & - & - \\
\hline
\end{tabular}

Source: MISSOC (several years); ILO 2007; ISSA 2008.

Table 4

Earnings taken as insurance scheme references

\begin{tabular}{llcc}
\hline & \multicolumn{1}{c}{ I991 } & I994 & I995 \\
\hline FR & last I2 M & - & - \\
DE & last 3 M & last 6 M & last I2 M \\
PT & I2 M preceding the 2 M prior to unemployment & - & - \\
SP & last 6 M & - & - \\
\hline
\end{tabular}

Source: MISSOC (several years); ILO 2007; ISSA 2008.

on the taxation system and incidence of social contributions, the gross and net rate of replacement may or may not coincide. In I99I, unemployment benefits in Germany, Portugal and Spain were subject to neither tax nor social contributions. France was the only country where benefits were subject to taxation (after a deduction) and social contributions which made the aforementioned gross rate less generous.

In respect of the earnings taken as reference, we find wide diversity in the time period over which benefit calculations were based (table 4). In I99I, it varied between three months (Germany) and I2 months (Portugal and France).

In addition, the setting of a maximum benefit amount (and/or a minimum) must be analyzed, because it 'breaches significantly the principle of equivalence or reciprocity i.e. the correspondence between contributions and benefit (Clasen 200I: 645). In Portugal and Spain, a maximum and a minimum amount are set; the Spanish scheme has a special feature, i.e. the minimum 
amount varies according to the number of dependent children. In France, there was only a minimum amount.

Over the period under review, none of the structural features of the insurance scheme was altered. However, we can identify some trends towards a new direction:

I. in Germany, the time period used to calculate the benefit was increased twice (in I994 and I995) and the benefit rates were decreased in I996, which produced a double effect towards a more restrictive entitlement, i.e. lower benefits;

2. in France, the sliding scale of benefits introduced in I992 was abandoned in 200I; in terms of the amount of benefit, the new fixed scale penalizes longer spells of unemployment less than its predecessor; and

3. in Spain, the maximum benefit became variable according to the number of children (I70 per cent, i95 per cent or 220 per cent of the minimum wage), replacing the previous single rate (220 per cent of the minimum wage), and the gross rates of replacement were reduced to 70 per cent and 60 per cent, which translates into lower benefits for beneficiaries with few or no dependent children; after I994, and following the French example, the benefits became subject to tax and social security contributions.

\section{Entitlement: duration of payment}

With regard to the duration of benefit payments, one of two principles are applied to insurance schemes: a fixed period or a variable maximum period which may be dependent on labour market status (the individual's employment record) and/or the personal status (age) (Kvist I998: 48).

In I99I, all the countries operated with variable periods but with different determining factors:

I. in France and Germany, the duration was positively related to the working record and age;

2. in Spain, the duration depended on the length of insurance; and

3. in Portugal, age was the guiding principle. Over the period, Portugal joined the first cluster (table 5).

In I99I, there was significant diversity in the duration of insurance benefits, especially in terms of the maximum duration with France running the most generous scheme and Spain the least. Over the period, payment durations have been successively but differently changed in three countries. Some convergence is observable in the maximum duration, which has been reduced in all three countries (twice in France and Germany), while the minimum duration has undergone an opposite change in France (increased) and Portugal (decreased). Some general trends may also be highlighted:

I. in all countries, the working record has become increasingly important in determining the payment duration (minimum and maximum); 
Table 5

Duration of payment: insurance schemes

\begin{tabular}{|c|c|c|c|c|c|c|}
\hline & I993 & I995 & I999 & 2002 & 2004 & 2006 \\
\hline FR & $\begin{array}{l}\text { M: } 4 \text { to } 6 o \\
\text { insurance } \\
\text { work and } \\
\text { age }\end{array}$ & & & M: 7 to 42 & & M: 7 to 36 \\
\hline DE & $\begin{array}{l}\text { M: } 6 \text { to } 3^{2} \\
\text { insurance } \\
\text { work and } \\
\text { age }\end{array}$ & $\begin{array}{l}\text { Shorter } \\
\text { duration } \\
\text { for older } \\
\text { unemployed }\end{array}$ & & & M: 6 to 24 & \\
\hline PT & $\begin{array}{l}\text { M: Io to } 30 \\
\text { age }\end{array}$ & & M: 12 to 30 & & & $\begin{array}{l}\text { M: } 9 \text { to } 24 \\
\text { age and } \\
\text { insurance } \\
\text { work }\end{array}$ \\
\hline SP & $\begin{array}{l}\text { M: } 4 \text { to } 24 \\
\text { insurance } \\
\text { work }\end{array}$ & & & & & \\
\hline
\end{tabular}

Source: MISSOC (several years); ILO 2007; ISSA 2008.

2. the duration has been tightened for older unemployed people in conjunction with a less favourable change for those with longer insurance records.

\section{What Has Been Ghanged and How?}

There is some evidence that the four selected countries have made changes to their unemployment protection schemes. Table 6 presents their directions by year and item.

The changes introduced in the four insurance schemes reveal restrictions in eligibility and entitlement criteria, although to different extents and with differing mixes of instruments. However, a common trend to all countries is highlighted: eligibility has been tightened by means of more restrictive payment conditions, mostly tighter claimant obligations.

Relating the mix of measures, France and Germany introduced legislative changes in almost all items concerning eligibility and entitlement. In contrast, Portugal has used the lowest number of instruments. Other differences among the four countries can be highlighted. In comparison with France, the measures adopted in Germany throughout this period were clearly oriented to a more restricted eligibility and lower generosity. In the case of France, expansive measures were implemented in 1996 and 200 I.

In addition to the smaller number of measures taken, in comparison with Spain, Portugal presented an important difference as regards the timing of reforms: while Spain implemented an important mix of legislative changes (all 
restrictive in nature) between 1992 and I994, Portugal undertook its first reform of unemployment protection (aimed at higher coverage and generosity) in I999. Restrictive measures were only introduced in the Portuguese insurance scheme from 200 onwards. Two reasons justify this difference in the timing of reforms:

I. the high rates of unemployment and consequent high social spending in Spain in the early gos;

2. the lowest degree of coverage in the Portuguese insurance scheme as compared with the former.

Regarding the characterization of reform trajectories, two conclusions stand out:

I. France and Germany recorded a trajectory very similar in terms of both the number of reform measures and their timing;

2. the two Mediterranean countries displayed different trajectories, Spain closer to other continental countries and Portugal with a very specific 'agenda'.

As regards identifying the respective trajectories over time, the unemployment reforms carried out by the four countries point to confirmation of the two already discussed stages in welfare reform. Between ig9i and I997, all countries, with the exception of Portugal, implemented legislative changes relating to the qualifying period, earnings references and replacement rates, duration of payments and incidence of taxation. This first wave of reforms seems clearly justified by concerns over controlling social expenditure and cost-containment more generally, deriving from the Maastricht process.

In the second wave of reforms, from 200I onwards, all countries placed the emphasis on stricter eligibility requirements and on the activation of unemployed people through stronger individual behaviour requirements, more monitoring and punitive sanctions. These political options, which clearly demonstrate lesser tolerance of long-term benefit dependency, may have their rationale based upon the potential of work disincentives. Indeed, this new conditionality may have a larger impact on unemployed behaviour than changes to all other entitlements and eligibility criteria: when an unemployed citizen becomes ineligible for benefits, the replacement rate falls to zero (OEGD 2000: I3I).

\section{Conclusion}

The purpose of this article is twofold. First, focusing on unemployment insurance schemes, the article analyzed the legislative changes concerning eligibility and entitlement criteria carried out over the I99I-2006 period in four countries (France, Germany, Portugal and Spain) in order to validate or dismiss the hypothesis that the reform process may have led to a new balance characterized by weaker social rights and stronger obligations. Second, the article sought to verify whether or not there was a common reform trajectory 
Table 6

Direction of changes

\begin{tabular}{|c|c|c|c|c|c|c|}
\hline \multirow[t]{2}{*}{ Year } & \multicolumn{2}{|c|}{ Eligibility } & \multicolumn{4}{|c|}{ Entitlement } \\
\hline & $\begin{array}{l}\text { Qualifying } \\
\text { period }\end{array}$ & $\begin{array}{l}\text { Terms of } \\
\text { payment }\end{array}$ & $\begin{array}{c}\text { Reference } \\
\text { Earnings }\end{array}$ & Rates & Duration & $\begin{array}{c}\text { Tax and SC } \\
\text { incidence }\end{array}$ \\
\hline I992 & $\begin{array}{l}\text { FR }(+R) \\
\text { SP }(+R)\end{array}$ & & & $\begin{array}{l}\text { FR }(-G) \\
\operatorname{SP}(-G)\end{array}$ & & \\
\hline I993 & & & & & & \\
\hline I994 & & & $\mathrm{DE}(-\mathrm{G})$ & & & SP $(-G)$ \\
\hline I995 & & & $\mathrm{DE}(-\mathrm{G})$ & & $\mathrm{DE}(-\mathrm{G})(\mathrm{a})$ & \\
\hline I996 & & & & $\mathrm{FR}(+\mathrm{G})$ & & \\
\hline I997 & & & & $\mathrm{DE}(-\mathrm{G})$ & & \\
\hline I998 & & $\mathrm{DE}(+\mathrm{R})$ & & & & \\
\hline I999 & & & & & PT $(+G)(b)$ & \\
\hline 2000 & & & & & & \\
\hline $200 \mathrm{I}$ & $\mathrm{FR}(-\mathrm{R})$ & $\begin{array}{l}\mathrm{FR}(+\mathrm{R}) \\
\mathrm{SP}(+\mathrm{R})\end{array}$ & & $\mathrm{FR}(+\mathrm{G})$ & & \\
\hline 2002 & $\mathrm{FR}(+\mathrm{R})$ & $\begin{array}{l}\mathrm{DE}(+\mathrm{R}) \\
\mathrm{SP}(+\mathrm{R})\end{array}$ & & & $\mathrm{FR}( \pm \mathrm{G})(\mathrm{c})$ & \\
\hline 2003 & & $\begin{array}{l}\mathrm{FR}(+\mathrm{R}) \\
\mathrm{DE}(+\mathrm{R}) \\
\mathrm{PT}(+\mathrm{R})\end{array}$ & & & & \\
\hline 2004 & $\mathrm{DE}(+\mathrm{R})$ & $\begin{array}{l}\mathrm{DE}(+\mathrm{R}) \\
\mathrm{SP}(+\mathrm{R})\end{array}$ & & & $\mathrm{DE}(-\mathrm{G})(\mathrm{a})$ & \\
\hline 2005 & & $\begin{array}{l}\text { FR }(+\mathrm{R}) \\
\mathrm{DE}(+\mathrm{R})\end{array}$ & & & & \\
\hline 2006 & & $\begin{array}{l}\mathrm{FR}(+\mathrm{R}) \\
\mathrm{DE}(+\mathrm{R})\end{array}$ & & & $\mathrm{FR}(-\mathrm{G})(\mathrm{a})$ & \\
\hline & & PT (+R) & & & PT $(-G)(d)$ & \\
\hline & & $\mathrm{SP}(+\mathrm{R})$ & & & & \\
\hline
\end{tabular}

Source: Elaborated by the author.

Notes: $\mathrm{R}=$ restrictive; $\mathrm{G}=$ generous; $+=$ more; $-=$ less.

(a) For older unemployed.

(b) Increase in the minimum duration.

(c) Increase and decrease in the minimum and maximum duration, respectively.

(d) Decrease in the minimum and maximum duration.

in time as well as in space given the known divergence over the classification of Mediterranean countries under a specific regime.

Analysis of the 25 legislative changes confirms the two reform agenda dimensions (cost-containment and the recalibration of benefit rights) identified by Clegg (2006). However, two issues must be highlighted. First, only two countries have chosen to reduce the generosity of benefits: Germany, where the rates of replacement were reduced in 1995 and the time period used to calculate benefits was increased in 1997, and Spain, which first cut 
replacement rates in 1992 and then subjected them to tax and social contributions in 1994 .

Second, access to unemployment insurance, including eligibility for continued receipt of benefit, became progressively more restrictive in all four countries, from 200 I onwards. In addition to a more stringent qualifying period in Germany (2004 reform) and a reduction in payment duration in Germany (2004 reform), Portugal and France (2006 reforms), beneficiary obligations have been heavily reinforced in all countries during the second wave of reforms. The new obligations have been accompanied by a more intensive monitoring of individual jobseeker activities as well as by tougher sanctions on those refusing re-qualification activities or job offers. Such political options seem to confirm the hypothesis of a new balance between weaker social rights and stronger obligations. As mentioned above, the four insurance schemes, as representatives of the conservative welfare regime, would grant unemployment protection based on the contributory principle, i.e. access was dependent on prior contributions and payment durations varied according to the individual's insurance career. Not only do we observe a reinforcement of the work-relatedness principle, a trend already found in some other countries before 2003 (Clasen and Clegg 2006; Clegg 2007), but we furthermore identify a new conditionality in terms of the right to protection. Indeed, the receipt of insurance benefits has become strictly dependent on actively searching for work, which may, in turn, reveal a reconstruction of social protection on the basis of future work prospects (Erhel and Zajdela 2004).

There is no doubt that the return to work strategy adopted in all countries 'has taken the lead over social protection of the worker in terms of objectives' (Clasen 2000: 38), regardless of empirical evidence that beneficiaries, mainly in more vulnerable groups, have been moved to low-paid and temporary jobs. Moreover, the consequences of efforts to restrict the alternatives to participation in the labour market may reflect a trend towards recommodification (Green-Pedersen 200I; Lindbom 2002), which fosters negative consequences: the exclusion of unemployed individuals for reasons unrelated to their personal circumstances or efforts, such as persistent unemployment and low levels of job creation.

As regards the second purpose of this article, the identification, or otherwise, of a common reform trajectory in time and in space, conclusions can also be drawn.

Regarding the first issue, we may conclude that no Mediterranean cluster was identified. Indeed, the two countries presented different trajectories with Spain closer to the other continental countries, which recorded very similar trajectories, and Portugal following its own very specific 'agenda'. Furthermore, the reform processes carried out by the four countries do seem to confirm the existence of two main stages to welfare reform: a first wave, between I99I and I997, when all countries with the exception of Portugal implemented legislative changes clearly reflecting concerns over cost-containment. Subsequently, a second wave of reforms, from 200I onwards, has been characterized by a stronger recalibration of rights and obligations. 


\section{Notes}

I. Taylor-Gooby analyzed attitude survey data (1985-96) in Sweden, Germany and the UK as representatives of the three regime types proposed by Esping-Andersen.

2. The International Reform Monitor is a project carried out by the Bertelsmann Foundation, which provides online information on social policy in ${ }_{5} 5$ OECD countries (Portugal not included). The ILO's NATLEX database provides abstracts of legislation.

3. In all countries, unemployed persons can claim unemployment assistance benefits when they are not eligible for insurance benefits or have exhausted entitlements to insurance benefits.

4. In Portugal, the creation of the Employment and Social Protection Programme, which included special (and temporary) measures for new claimants from March 2003, had no effect on the ratio. For more details, see MISSOC-Info or/2004.

5. For more detailed analysis of activation policies, see, for example, Clasen (2002: Part C, pp. 197-255), Barbier and Ludwing-Mayerhofer (2004) and Dingeldey (2007).

\section{References}

Allan, J. and Scruggs, L. (2004), Political Partisanship and Welfare State Reform in Advanced Industrial Societies, American Fournal of Political Science, 48, 3: 496-512.

Arcanjo, M. (2006), Ideal (and real) types of welfare state, WP o6/2006/DE, Lisbon: Technical University of Lisbon.

Barbier, J. and Ludwing-Mayerhofer, W. (2004), Introduction: the many worlds of activation, European Societies, 6, 4: 423-36.

Bonoli, G. (1997), Classifying Welfare States: a Two-dimension Approach, fournal of Social Policy, 26, 3: 35 I-72.

Bonoli, G. (2003), Two worlds of pension reform in western Europe, Comparative Politics, 35, 4: 399-416.

Bonoli, G. and Palier, B. (2007), When past reforms open new opportunities: comparing old-age insurance reforms in Bismarckian welfare systems, Social Policy $\mathcal{E}^{2}$ Administration, 4I, 6: 555-73.

Castles, F. (2004), The Future of the Welfare State: Crisis Myths and Crisis Realities, Oxford: Oxford University Press.

Castles, F. (2008), What welfares states do: a disaggregated expenditure approach, Journal of Social Policy, 38, I: 45-62

Clasen, J. (2000), Motives, means and opportunities: reforming unemployment compensation in the I99os, West European Politics, 23, 2: 89-112.

Clasen, J. (200I), Social Insurance and the Contributory Principle: a paradox in contemporary British Social Policy, Social Policy \& Administration, 35, 6: 64I-57.

Clasen, J. (ed.) (2002), What future for social security? Debates and reforms in national and cross-national perspectives, Bristol: Policy Press.

Clasen, J. and Clegg, D. (2006), Beyond activation: reforming European unemployment protection systems in post-industrial labour markets, European Societies, 8, 4: $527-53$.

Clasen, J., Kvist, J. and van Oorschot, W. (200I), On condition of work: increasing work requirements in unemployment compensation schemes. In M. Kautto, J. Fritzell, B. Hvinden, J. Kvist and H. Uusitalo (eds), Nordic Welfare States in the European Context, London: Routledge, pp. I98-23I.

Clegg, D. (2006), Unemployment policy reform in 'Bismarckian' welfare states. The cases of Belgium, France, Germany and the Netherlands, paper prepared for the Conference 'A 
long goodbye to Bismarck? The politics of welfare reforms in continental Europe', Harvard University, I6/ I7 June.

Clegg, D. (2007), Continental drift: on unemployment policy change in Bismarckian Welfare States, Social Policy \& Administration, 4I, 6: 597-6I7.

Clegg, D. and Clasen, J. (2003), Conceptualising and measuring the changing principles of social security in Europe: reflections from a five country study, paper presented at the ESPA annual conference Changing European Societies - the role of social policy, Copenhagen, I3-I5 November.

Dingeldey, I. (2007), Between workfare and enablement - the different paths to transformation of the welfare state: a comparative analysis of activating labour market policies, European Fournal of Political Research, 46: 823-51.

Eichhorst, W. and Konle-Seidl, R. (2008), Contingent convergence: a comparative analysis of activation policies, DP No. 3905, Bonn: Institute for the Study of Labor.

Erhel, C. and Zajdela, H. (2004), The dynamics of social and labour market policies in France and the United Kingdom: between path dependence and convergence, Journal of European Social Policy, I4, 2: 125-42.

Esping-Andersen, G. (1990), The Three Worlds of Welfare Capitalism, Cambridge: Polity Press and Princeton, NJ: Princeton University Press.

Esping-Andersen, G. (I999), Social Foundations of Post-Industrial Economies, Oxford, Oxford University Press.

European Commission (EC) (1993), Social Protection in Europe, Brussels: EC.

Eurostat (200I), European Social Statistics. Social protection. Expenditures and Receipts. Data 1980-1999, Luxembourg: Office for Official Publications of the European Communities.

Eurostat (2004), European Social Statistics. Social protection. Expenditures and Receipts. Data I992-200I, Luxembourg: Office for Official Publications of the European Communities.

Eurostat (2008a), Database on Living Conditions and Welfare, Luxembourg: Office for Official Publications of the European Communities, http://epp. eurostat.ec.europa.eu (accessed i5 January 2010).

Eurostat (2008b), European Social Statistics. Social protection. Expenditures and Receipts. Data 1997-2005, Luxembourg: Office for Official Publications of the European Communities.

Ferrera, M. (1996), The 'Southern' Model of Welfare State in Social Europe, fournal of European Social Policy, 6, I: i7-37.

Ferrera, M. and Rhodes, M. (eds) (2000), Recasting European Welfare States, London: Frank Cass.

Gallie, D. and Paugam, S. (2000), The experience of unemployment in Europe: the debate. In D. Gallie and S. Paugam (eds), Employment precarity, unemployment, and social exclusion, Oxford: Oxford University Press, pp. I-22.

Gough, I. (200I), Social assistance regimes: a cluster analysis, Fournal of European Social Policy, II, 2: 165-70.

Green-Pedersen, C. (200I), Welfare state retrenchment in Denmark and the Netherlands, I982-I998. The role of the party competition and party consensus, Comparative Political Studies, 34, 9: 963-85.

Green-Pedersen, C. (2004), The dependent variable problem within the study of welfare state retrenchment: defining the problem and looking for solutions, fournal of Comparative Policy Analysis, 6, I: $3^{-\mathrm{I}} 4$.

Hemerijck, A. and Eichhorst, W. (2009), What happened to the Bismarckian welfare state? From labor shedding to employment-friendly reforms, DP No. 4085, Bonn: Institute for the Study of Labor. 
Huber, E. and Stephens, J. (2001), Development and Crisis of the Welfare States: Parties and Politics in Global Markets, Chicago, IL: University of Chicago Press.

International Labour Office (ILO) (2007), NATLEX database on national labour, social security and related human rights legislation, Geneva: ILO, http://www.ilo.org (accessed I5 January 20I0).

International Reform Monitor (n/d), Online database on social policy, Bertelsmann Foundation, http://www.reform-monitor.org (accessed I5 January 20I0).

International Social Security Association (ISSA) (2008), Social Security Databases, http:// www.issa.int/aiss/Observatory/Social-Security-Databases (accessed I5 January 20IO).

Jochem, S. (2007), Pension reform: beyond path-dependency? In J. Clasen and N. Siegel (eds), Investigating Welfare Change - The dependent variable problem in comparative welfare state analysis, Cheltenham: Edward Elgar, pp. 26I-80.

Katrougalos, G. S. (I996), The South European Welfare Model: the Greek Welfare State in Search of Identity, Fournal of European Social Policy, 6, I: 39-6o.

Kautto, M. (2002), Investing in services in West European welfare states, Fournal of European Social Policy, I2, I: 53-65.

Kittel, B. and Winner, H. (2005), How reliable is pooled analysis in political economy? The globalisation-welfare state nexus revisited, European Fournal of Political Research, 44, 2: $269-93$.

Korpi, W. (2003), Welfare state regress in western Europe: politics, institutions, globalisation and Europeanization, Annual Review of Sociology, 29: 589-6o9.

Korpi, W. and Palme, J. (2003), New politics and class politics in the context of austerity and globalisation: welfare state regress in I8 countries, 1975-95, American Political Science Review, 97, 3: 425-46.

Kuhnle, S. (ed.) (2000), Survival of the European Welfare State, London: Routledge.

Kvist, J. (I998), Complexities in assessing unemployment benefits and policies, International Social Security Review, 51, 4: 33-55.

Kvist, J. (2000), Changing rights and obligations in unemployment compensation: using fuzzy set theory to explore the diversity of Northern European policy development in the Ig9os, paper presented to the International Research Conference on Social Security 'Social security in the global village', Helsinki, $25^{-27}$ September.

Leibfried, S. (I992), Towards a European welfare state? On integrating Poverty Regimes into the European Community. In Z. Ferge and J. E. Kolberg (eds), Social Policy in a Changing Europe, Frankfurt: Campus Verlag.

Lindbom, A. (2002), The politics of welfare state reform, Fournal of European Public Policy, 9, 2: 3I I-2I.

MacMenamim, I. (2003), Is there an East-Central European Variety of Democratic Capitalism? A Twenty-Two Country Cluster Analysis, Dublin: Centre for International Studies, WP No. 5 .

MISSOC (several years), Social Protection in the Member States of the European Union, Luxembourg: European Commission.

Myles, J. and Quadagno, J. (I997), Recent Trends in Public Pension Reform: a Comparative View. In K. Banting and R. Broadway (eds), Reform of Retirement Income Policy. International and Canadian Perspectives, Kinston, Ontario: School of Policy Studies, pp. 247-72.

Organisation for Economic Co-operation and Development (OECD) (2000), Employment Outlook, Paris: OECD.

Organisation for Economic Co-operation and Development (OECD) (2005), Employment Outlook, Paris: OECD.

Organisation for Economic Co-operation and Development (OECD) (2006), Employment Outlook, Paris: OECD. 
Organisation for Economic Co-operation and Development (OECD) (2007), Employment Outlook, Paris: OECD.

Organisation for Economic Co-operation and Development (OECD) (2008), OECD Stat Extracts, http://stats.oecd.org (accessed I5 January 20I0).

Palier, B. (2007), The politics of reforms in Bismarckian welfare systems, paper presented to the Biennial Conference, European Union Studies Association, I7-I9 May, Montreal, Canada.

Palier, B. and Martin, C. (2007), From a 'frozen landscape' to structural reforms: the sequential transformation of Bismarckian welfare systems, Social Policy $\mathcal{E}$ Administration, 4I, 6: 535-54.

Pallage, S., Scruggs, L. and Zimmermann, C. (2008), Unemployment insurance generosity: a Trans-Atlantic Comparison, DP No. 3869, Bonn: Institute for the Study of Labor.

Palme, J., Nelson, K., Sjöberg, O. and Minas, R. (2009), European Social Models, Protection and Inclusion, Research Report, Götzens: Institute for Futures Studies.

Pierson, P. (1996), The New Politics of Welfare State, World Politics, 48, 2: 143-79.

Pierson, P. (2001a), Post-industrial pressure on the mature welfare states. In P. Pierson (ed.), The New Politics of the Welfare State, Oxford: Oxford University Press.

Pierson, P. (200Ib), Coping with Permanent Austerity: welfare state restructuring in affluent Democracies. In P. Pierson (ed.), The New Politics of the Welfare State, Oxford: Oxford University Press, pp. 410-56.

Powell, M. and Barrientos, A. (2004), Welfare regimes and welfare mix, European Journal of Political Research, 43: 83-105.

Powell, M. and Barrientos, A. (201I), An Audit of the Welfare Modelling Business, Social Policy \& Administration, 45, I: 69-84.

Powell, M. and Hewitt, M. (2002), Welfare State and Welfare Change, Buckingham: Open University Press.

Saint-Arnaud, S. and Bernard, P. (2003), Convergence ou résilience? Une analyse de classification hiérarchique des régimes providentiels des pays avancés, Sociologie et Sociétés, 35, г: 65-93.

Schludi, M. (2005), The reform of Bismarckian pension systems: a comparison of pension politics in Austria, France, Germany, Italy and Sweden, Amsterdam: Amsterdam University Press.

Scruggs, L. (2006), The generosity of social insurance, I971-2002, Oxford Review of Economic Policy, 22, 3: 349-64.

Soede, A. J. et al. (2004), Unequal Welfare States. Distributive consequences of population ageing in six European countries, The Hague: Social and Cultural Planning Office (SCP).

Taylor-Gooby, P. (I999), Policy change at a time of retrenchment: recent pension reform in France, Germany, Italy and the UK, Social Policy $E^{2}$ Administration, 33, I: I-I9.

Taylor-Gooby, P. (200I), Sustaining state welfare in hard times: who will foot the bill? Fournal of European Social Policy, II, 2: 133-47.

Vogel, J. (2003), Welfare State, Social Indicators Research, 64: 373-91.

Zimmermann, B. (2006), Changes in work and social protection: France, Germany and Europe, International Social Security Review, 54, 4: 29-45. 